\title{
Encoding three-participant events in the Lao clause ${ }^{1}$
}

\author{
N. J. ENFIELD
}

\begin{abstract}
Any language will have a range of predicates that specify three core participants (e.g. 'put', 'show', 'give'), and will conventionally provide a range of constructional types for the expression of these three participants in a structured single-clause or single-sentence event description. This article examines the clausal encoding of three-participant events in Lao, a Tai language of Southeast Asia. There is no possibility in Lao for expression of three full arguments in the core of a single-verb clause (although it is possible to have a third argument in a noncore slot, marked as oblique with a prepositionlike element). Available alternatives include extraposing an argument using a topic-comment construction, incorporating an argument into the verb phrase, and ellipsing one or more contextually retrievable arguments. A more common strategy is verb serialization, for example, where a threeplace verb (e.g. 'put') is assisted by an additional verb (typically a verb of handling such as 'carry') that provides a slot for the theme argument (e.g. the transferred object in a putting scene). The event construal encoded by this type of structure decomposes the event into a first stage in which the agent comes into control over a theme, and a second in which the agent performs a controlled action (e.g. of transfer) with respect to that theme and a goal (and/or source). The particular set of strategies that Lao offers for encoding three-participant events - notably, topic-comment strategy, ellipsis strategy, serial verb strategy — conform with (and are presumably motivated $b y$ ) the general typological profile of the language. The typological features of Lao are typical for the mainland Southeast Asia area (isolating, topic-prominent, verb-serializing, widespread nominal ellipsis).
\end{abstract}

\section{Introduction}

Verbs such as 'send' or 'put', which specify three participants, pose a coding challenge to languages everywhere. Beyond the already broad 
range of options for distinguishing between a first and second argument in descriptions of two-participant events, and given a general preference for minimizing the number of lexical arguments per clause (DuBois 1987), the need to fit yet a third argument into the clause complicates matters considerably. Typological discussion of three-place predicates has paid special attention to the differential morphosyntactic treatment of theme and goal arguments (especially where "double objects" are involved), given the logical possibilities of singling out one of these for the standard treatment received by grammatical object or equivalent in two-argument constructions, and treating the other as somehow special (cf. Borg and Comrie 1984; Givón 1984; Dryer 1986; Bresnan and Moshi 1990; Hudson 1992; Baker 1996; Bresnan 2001). This article takes a broader perspective on the problem of three-participant events and their grammatical management, following work such as Newman (1996) and Margetts and Austin (this issue). The aim is to describe the array of resources made available in a single language system for the encoding of three-participant events, and to see how this set of resources coheres given the typological profile of the language. The language is Lao, a Southwestern Tai language of Laos, Thailand, and Cambodia. The closest to a Lao exponent of the "double object" type structure involves postverbal incorporation of the theme nominal (Section 3.1). When only one verb is present in a clause, the threeargument problem is otherwise dealt with by extraposition of one of the nonsubject arguments (Section 3.2) ellipsis of arguments where contextually retrievable (Section 3.3), or marking off of one argument in an oblique (prepositional) phrase (Section 5). Verb serialization (Section 4) is the more productive strategy for hosting multiple nonsubject arguments.

The set of resources conventional in Lao constitute a subset of the fuller taxonomy of strategies currently attested across languages (Margetts and Austin this issue, based on Austin et al. 2000):

(1) Taxonomy of encoding strategies of three-participant events (simplified and adapted from Margetts and Austin this issue) Lao strategies given in italics:

a. Three-place predicate strategy: all three participants are expressed as syntactic arguments of the verb [Lao strategies involve topicalization and ellipsis; Section 3];

b. Oblique strategy: verb takes two arguments, a third participant is expressed as oblique (by case marking or adposition) [Lao strategy involves adpositional marking of a goal participant; Section 5]; 
c. Serial verb strategy: two or more verbs combine in a single clause to share the three arguments [Section 4];

d. Incorporation strategy: one participant is incorporated, not a full argument [Lao strategy involves incorporation of theme, goal is a regular object; Section 3];

e. Adnominal strategy: one participant is expressed as adnominal dependent of an argument;

f. Directional strategy: an adverbial directional marker indicates deictic orientation of transfer event;

g. Absorption strategy: the verb includes information about a third participant. ${ }^{2}$

Expanding upon previous work on 'give' in Lao (Enfield 2002), this article presents a more comprehensive survey of the range of possibilities an individual language provides for accommodating reference to three eventparticipants in a single clause or sentence. Broad typological and theoretical research on the grammatical expression of three-participant events will not be possible without such overviews for languages of different types. The present case represents the classic isolating, analytic type (Sapir 1921). Typical of a mainland Southeast Asian language, Lao grammar overcomes a constraint against three overt, full arguments in the core of a single-verb clause by utilizing a number of definitive features of the language's overall typological profile - topic-comment structure, definite argument ellipsis, and verb serialization.

\section{Preliminaries}

\subsection{Some terminological distinctions}

A participant in an event is any entity that can be thought of as directly involved in that event. Any verb will specify some minimum number of participants in the event that it predicates, such that the event it denotes cannot be imagined with fewer participants. For example, sleep specifies at least one participant, forget at least two, and show at least three. An argument, by contrast, is a syntactic entity, a clause-level reference to a participant that is fully referential and trackable in the discourse, freely expandable and modifiable, and occupies a grammatical "slot" (cf. Goldberg 1995: 43). Arguments are a subset of participants. Thus, while the event denoted by the verb paint involves no less than four participants (a painter, some paint, an instrument such as a brush, and a thing to which the paint is applied), the number of arguments encoded in a description of 
this event may be just two (I painted the house). I refer in this article to the participants specified in a three-participant event as source, theme, and goal, identified in Langacker's terms as being at the beginning, middle, and end, respectively, of an action chain (Langacker 1991: Chapter 9). In a 'give' event, these correspond to 'giver', 'gift', and 'recipient'.

\subsection{Preliminaries on Lao clause organization}

The basic Lao clause is (schematically) organized as follows:

\section{(2) (Left Pos.) / SubJ AM-[V (ObJ)]-AM final-PCls \(Right Pos.)}

Forward and back slashes represent left and right borders, respectively, of the clausal core. Left Position is an extraclausal "topic" slot that may contain any nominal whether an argument of the verb or not. It may also contain phrases, clauses, or even whole sentences. This feature is fundamental in the language's sentential organization, as has been observed for languages throughout the Southeast Asia region ( $\mathrm{Li}$ and Thompson 1976). Subject here refers to an S/A pivot (Dixon 1994: 112), less pervasive in the organization of Lao grammar than, say, subject in English. For instance, subject determines equi control but does not play a role in the organization of relative clauses or reflexive constructions. ${ }^{3}$ Noun phrases in almost any position may be ellipsed if reference is contextually retrievable. Exceptions include complements of certain prepositions such as caak5 'from', kap2 'with', and kèèl 'to'. Indeed, a syntactic requirement for a noun phrase to be explicitly mentioned is less common in Lao than a requirement that it be ellipsed. A number of control constructions require certain arguments to be omitted when subjects of structurally related clauses are coreferential. Movement of core arguments, based on their discourse status, is common, particularly fronting (into Left Position), as well as postposing (into Right Position). Classifier phrases, which host the range of nominal modifiers including adjectives, determiners, quantifiers and numerals may be separated and moved away from the lexical noun in a kind of modifier float (Enfield 2004). "AM" refers to aspect-modality marking of various kinds, both preverbal and postverbal. "Final pcls" are sentence-final particles that encode a range of illocutionary force distinctions. These constitute a robust syntactic end border of the clausal core. Right Position is an extraclausal slot for various types of clausal increment, marked off prosodically with lowering of volume and pitch. 


\section{Single-verb means for expression of three participants in an event}

It is not possible in Lao to describe a three participant event where all three appear as full arguments in the clausal core with a single verb. Expressing three nominals with one verb in a single utterance requires "burying" one of the arguments with incorporation, extraposing one of the arguments with topicalization, or deleting one or more arguments with ellipsis.

\subsection{Incorporation strategy}

A number of three-participant verbs (including thaam3 'ask', bòòk5 'tell', thaa2 'apply, smear') allow two complements to appear postverbally, with neither overtly marked as oblique (e.g. by a preposition-like element). Theme (TH) participants precede goal/recipient participants: ${ }^{4}$
(3) khian3 [qanø-nan4 $]_{\mathrm{TH}} \quad$ [phen1] vaj4 vaal siø bòø write CLF-DEM.NONPROX 3 HON keep say IRR NEG dajø maa2.
ATTN come
'(I) write them a whatdoyoucallit [lit. 'a "that-thing"' '], telling (them I) won't be coming (back).'
(551.5)
(4) khòoj5 thaam3 [moong2 $]_{\mathrm{TH}}$ [laaw2].
$1 \mathrm{sG}$ ask o'clock 3sG
'I asked him/her the time.'
(5) caw5 haj5 [thaang2 $]_{\mathrm{TH}}$ [phen1] dèè1.
$2 \mathrm{SG}$ give way $3 \mathrm{HON}$ PCL
'You please make way (for) him.'

These structures can be said to involve incorporation in that the first postverbal nominal - the theme argument - virtually forms a single predicate in combination with the verb, and this predicate may then take a direct complement. The incorporated nominal is not freely modifiable in situ. (A modifier is possible if fully extraposed, appearing in Right Position.) In the following example, sii3 'paint' is an incorporated complement of thaa2 'apply', resulting in thaa2 sii3 [apply-paint] 'apply paint to', or simply 'to paint':

(6) laaw2 thaa2 sii3 hùan2 lang3 nii4. 3SG apply paint house CLF DEM.GEN 'S/he painted (i.e. 'applied paint (to)') this house.' 
Accordingly, sii3 'paint' in this context cannot be given extra weight with a direct modifier (luam5 'shiny' in [6]) or specifier (nan4 'that' in [7]):

(7) *laaw2 thaa2 sii3 lùam5 hùan2 lang3 nii4. 3SG apply paint shiny house CLF DEM.GEN '(S/he applied shiny paint to this house.)'

(8) *laaw2 thaa2 sii3 nan4 hùan2 lang3 nii4. 3SG apply paint that house CLF DEM.GEN '(S/he applied that paint to this house.)'

If a modifier or specifier is to combine directly with the theme sii3 'paint', then another strategy is required. The main three strategies are discussed in detail in later sections, but I shall first briefly introduce them here.

One possibility is to topicalize either the goal (9a) or theme argument (9b), putting one argument into a noncore slot.

(9) a. [hùan2 lang3 nii4 $]_{\mathrm{GOAL}}$ laaw2 thaa2 sii3 lùam5. house CLF DEM.GEN 3SG apply paint shiny 'This house s/he applied shiny paint (to).'

b. [sii3 lùam5 $]_{\mathrm{TH}}$ laaw2 thaa2 hùan2 lang3 nii4. paint shiny 3SG apply house CLF DEM.GEN 'Shiny paint s/he applied (to) this house.'

A second possibility is verb serialization (10), in which the theme is direct complement of V1 and the goal is direct complement of V2, thus making each nonsubject participant a complement of a separate verb.

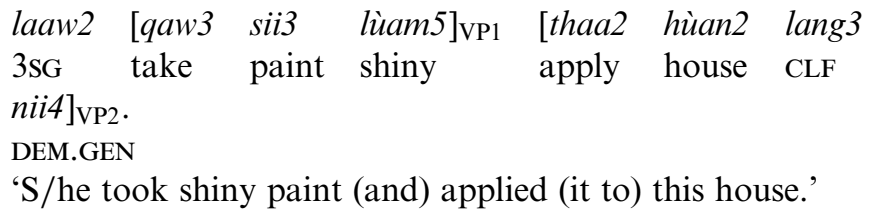

The third possibility is to adopt an oblique strategy (11), in which either the theme or goal argument is marked off by a preposition-like element in a noncore phrase (see sections below for discussion of these strategies):
a. laaw2 thaa2 hùan2 lang3 nii4 duaj4 sii3 3SG apply house CLF DEM.GEN with paint lùam5.
shiny
'S/he applied this house with shiny paint.'
b. laaw2 thaa2 sii3 lùam5 saj1 hùan2 lang3 nii4. 3sG apply paint shiny put house CLF DEM.GEN 'S/he applied shiny paint to this house.'


The productivity of the noun-incorporating strategy is apparently constrained to the expression of events in which the specific noun-verb combination is an everyday or typical one (cf. Mithun 1984: 861). The incorporated participant is usually if not always nonreferential/nonspecific. Here are further examples, involving hotl 'pour (water on something)' and pò̀n 4 'feed':

(12) khaw3 hot1 nam4 suan3.
3PL pour water garden
'They watered the garden.' (lit. 'They water-poured the garden.')
(13) man2 pò̀n4 khaw5 luuk4.
3sG feed rice child
'S/he fed (his/her) child.' (lit. 'S/he rice-fed (his/her) child.')

In these examples, the incorporated nominals nam4 'water' and khaw5 'rice' are not referential, in that they cannot be immediately referred to in the following discourse with pronominal (including zero) reference, and indeed in the case of (13) what is fed to the child need not even be rice. This shows that these expressions, while including three separate nominals in surface syntax, are not three-place predicates in a full sense. This is because the incorporated nominal is not a single phrase structure constituent (although it does display partial argument status, in allowing modification at all).

In further examples, it is even clearer that the surface exponents of three or more participants associated with a single lexical verb do not correspond to distinct referential arguments of the proposition. As in examples (12) and (13), the following involves one verb and three distinct nominals in a single clause:

(14) khòoj5 mii2 hèèn2 $\quad$ khaa3.
1sG have strength leg
'I feel good (in) my leg(s).'

The noun-verb combination mii2 hèèng2 literally means 'have strength', but the complement hèeng2 'strength' is not referential here. It is not that mii2 'have' in (14) subcategorizes for three arguments. Rather, the expression miiz hèeng2 'have strength' is a lexicalized predicate, which may either be used intransitively (meaning 'feel good'), or may take its own body-part complement (e.g. khaa3 'leg' in this example) in an "experiencer-locus" construction (Enfield in press).

The next example (attested in spontaneous use) shows four nominals in combination with a single verb: 
(15) man2 qòòk5 kamlang2 kaaj3 paak5.

$3 \mathrm{sg}$ expend energy body mouth

'S/he's exercising her mouth (by chewing gum).'

Here, the expression qò̀k5 kamlang2 - literally 'expend energy' — has developed a simple meaning 'exercise', and has come to habitually (although not obligatorily) take a further nominal complement kaaj3 'body' in a complex expression qòòk5 kamlang2 kaaj3 [expend energy body] 'exercise the body'. This expression, while on the surface showing two nominal complements, may in turn be considered a simple predication, whereby kaaj3 'body' (in the manner of khaw5 'rice' in [13], above) is not only nonreferential, but not even necessarily a literal complement of the verb at all. In (15), qòok5 kamlang2 kaaj3 is used as a notionally simple predicate 'exercise oneself', taking paak5 'mouth' as complement (i.e. not entailing that 'the body' itself is exercised, despite explicit presence of the nominal kaaj3 'body' as complement).

Examples such as (14) and (15) demonstrate the expression in a singleverb clausal core of more than two nominals as a purely surface phenomenon, not directly mapping to participants in event structure, nor to arguments in syntactic structure.

\subsection{Topicalization strategy}

The topic-comment construction is the only construction in which genuine three-participant verbs such as transfer verbs haj5 'give' and songl 'send' and placement verb saj1 'put (in)' allow full expression of three referential and modifiable noun phrases in a single sentence with no supporting morphology. However, because one of the arguments must appear in the extraclausal Left Position, it is not the case that this construction features three full arguments together in the clausal core. In this construction, the agent is expressed as subject (i.e. the nominal immediately before the verb), and the theme and goal appear in Left Position and object position (with both logical orders possible - namely, giving either $\mathrm{NP}_{\text {THEME }}-\mathrm{NP}_{\mathrm{AGENT}}-\mathrm{V}-\mathrm{NP}_{\mathrm{GOAL}}$ or $\mathrm{NP}_{\mathrm{GOAL}}-\mathrm{NP}_{\mathrm{AGENT}}-\mathrm{V}-$ $\mathrm{NP}_{\text {THEME}}$ ):

$\begin{array}{lllll}\text { (16) }\left[\begin{array}{llll}\text { ngen2 } & \text { haa5-lòj4 } & \text { kiip5 }\end{array}\right]_{\mathrm{TH}} & \text { qaaj5 } & \text { khòoj5 } & \text { haj5 } \\ \text { money five-hundred kip } & \text { O.BRO } & 1 \mathrm{SG} & \text { give } \\ {[\text { phuø-saaj2 phuø-nan4 }]_{\mathrm{GOAL}}} & & \\ \text { CT.PERSON-man CT.PERSON-DEM.NONPROX } & \\ \text { 'Five hundred kip, my brother gave that man.' }\end{array}$


(17)

$\begin{array}{lllllll}{\left[\begin{array}{lll}\text { tuu4 } & \text { nuaj1 } & \text { nan4 }\end{array}\right]_{\mathrm{GOAL}}} & \text { mia2 } & \text { khòòj5 } & \text { saj1 } & {[\text { pùm4 }} \\ \text { cupboard } & \mathrm{CLF} & \text { DEM.NONPROX } & \text { wife } & 1 \mathrm{SG} & \text { put } & \text { book } \\ \text { khòong3 } & \text { caw4 } 4]_{\mathrm{TH}} & & & & & \\ \text { of } & 2 \mathrm{SG} & & & & \end{array}$

'That cupboard, my wife put your books (in).'

\subsection{Ellipsis}

A more common strategy than the above two for solving the no-morethan-two-full-surface-arguments-per-single-verb-clausal-core constraint is for topical arguments to be ellipsed (assuming contextual retrievability), with the result that fewer than three arguments receive surface realization. Any three-participant verb may appear with only two participants (or fewer) expressed, as long as the discourse identity of the relevant three participants is clearly understood from the context. The second line of the following example illustrates:

caw4 jaak5 daj4 ñang3 nèèw2-daj3 khòoj5 mii2
2sG want acquire what type-which $1 \mathrm{SG}$ have
khòoj5 haj5 caw4.
1SG give 2sG
'(If) you want to get anything of any kind that I have - I'll give
(it to) you.'
$(408.5)$

Here is another example, involving the verb fang3 'bury':

(19) haw2 kaø khut2 khum3 - qaw3 saw3 fang3 Ø mèèn1 bòø- lang3-caak5 qaw3 saw3 fang3 Ø lèè 4...

PCL(Q) back-from take post bury PFV

'Then we dig a hole, and plant the post (in it), right? (Then,) after we've planted the post ...' (21.13)

The string qaw3 saw3 fang3 [take post bury] looks like a two-verb "handling-dispatch" structure (see Section 2.1 below). Informants generally agree that the default referent of ' $\varnothing$ ' in (19) is $\operatorname{din} 3$ 'earth, ground', 5 which has presumably been ellipsed under contextual retrievability. It could just as well be explicitly expressed, as follows:

(20) qaw3 saw3 fang3 din3.

take post bury earth

'(S/he) buried the post in the ground.' 
However, surface structures even leaner than qaw3 saw3 fang3 [take post bury] in (19) are possible, as long as the ellipsed arguments are available in the context:

(21) fang3 saw3

bury post

'(S/he) buried the post (in the ground).'

(22) fang3 din3

bury ground

'(S/he) buried (it) in the ground.'

(23) fang3

bury

'( $\mathrm{S} / \mathrm{he})$ buried (it in the ground).'

Note here that fang3 'bury' cannot be used in an incorporating construction:

(24) *fang3 saw3 din3

bury post ground

'( $\mathrm{S} /$ he buried the post (in) the ground.)'

As long as semantic roles of nominals are clear, verbs such as fang 3 'bury' and haj5 'give', which describe three-participant events, can be, and often are, treated as simple transitive or intransitive verbs (in that one or two of their three arguments goes unrealized), or may even appear without overtly expressed arguments at all.

The following example shows an unusual case, involving the threeparticipant verb sùu 4 'buy', where the theme is ellipsed and the verb takes a source as complement, with no peripheral marking (i.e. where 'buy it from them' is expressed as, literally, 'buy them', meaning 'buy-from them'):

caw4 caang4 lot1-camboo4 mùa2 lèè4 cang1 khòò1
2SG hire vehicle-jumbo return $\mathrm{PFV}$ then PCL
qanaa1 pajø qaw3 ngen2 lèew4 cùng1 maø sùu4
HES.PCL go take money PFV then come buy
khacaw4 saa3
3PL PCL
'You hire a jumbo [a type of local transport] and go back, then
um - go and get some money, and then come and buy (it from)
them, why don't you?' (218)

\subsection{Variations and complications, illustrated with reference to 'give'}

The possibilities of movement and ellipsis of arguments, combined with the linear separability of nominal heads and their modifiers in Lao phrase 
structure, result in a range of cases that on initial inspection appear to counterexemplify the analysis offered so far. This section considers these cases and clarifies how underlying structure can be established despite variable surface form. The discussion is restricted to haj5 'give' as an illustration.

First consider the following examples, showing haj5 'give' in the topicalization and incorporation structures, respectively:

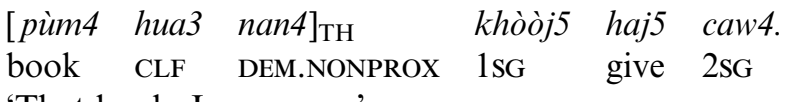

'That book, I gave you.'

(Structure: $\mathrm{NP}_{\text {THEME }}-\mathrm{NP}_{\mathrm{AGENT}}-\mathrm{V}_{\text {give }}-\mathrm{NP}_{\mathrm{GOAL}}$ )

(27) mèè dajø haj5 [sanñaa2 $]_{\mathrm{TH}}$ [phañaa2-sùa $]_{\mathrm{GOAL}}$

mother ATTN give promise king-tiger

vaj4.

fix.in.place

'The mother did give the tiger king a promise.' (851.4)

(Structure: $\mathrm{NP}_{\mathrm{AGENT}}-\mathrm{V}_{\text {'give }}-\mathrm{NP}_{\mathrm{THEME}}-\mathrm{NP}_{\mathrm{GOAL}}$ )

There are examples that show two nominals postverbally, but in which their relative ordering is goal-theme, in contrast to the order illustrated in (27):

(28) caw4 haj5 $[\text { khòòj5 }]_{\mathrm{GOAL}} \quad[\text { haa5-lòòj4 kiip5 }]_{\mathrm{TH}}$

2SG give 1SG five-hundred kip

'You gave me 500 kip.'

(Structure: $\mathrm{NP}_{\mathrm{AGENT}}-\mathrm{V}_{\text {'give' }}-\mathrm{NP}_{\mathrm{GOAL}}-\mathrm{NP}_{\mathrm{THEME}}$ )

Consider, however, the following ungrammatical example, with the same constituent order as (28), but with the simple noun ngen 2 'money' substituted for the classifier phrase haa5-lòoj4 kiip5 '500 kip' in the $\mathrm{NP}_{\mathrm{THEME}}$ position of (28):

$\begin{array}{lll}{ }^{*} \text { caw4 haj5 }[\text { khòoj5 } 5]_{\mathrm{GOAL}} & {[\text { ngen2 }]_{\mathrm{TH}}} \\ \text { 2SG give } 1 \mathrm{sG} & \text { money } \\ \text { '(You gave me money.)' } & \end{array}$

The ordering in (28) is not structurally equivalent to that in (29). This can be argued to result from a combination of zero anaphora (i.e. ellipsis of a would-be incorporated theme argument) and "floating" nominal modification (allowed by the nonconfigurational nature of the noun phrase; Enfield 2004; cf. Gil 1987). The phrase haa5-lòoj4 kiip5 'five hundred kip' is a classifier phrase that quantifies ngen 2 'money'. Example (28) may thus be analyzed as having a "zero" in the immediate postverbal theme slot, with the modifying classifier phrase haa5-lòoj4 kiip5 'five hundred kip' in 
sentence-final Right Position, outside the clausal core and not contiguous with its notional head noun ngen2 'money', as made explicit in (30). (In both examples [30] and [31], evidence that the modifying classifier phrase haa5-lòoj4 kiip5 'five hundred kip' is extraclausally "right-positioned" is provided by the insertability of sentence-final illocutionary particles immediately BEFORE them, and immediately after the goal argument khòjj5 ' $I$ '. The modifying material is not in core argument position.) The full structure, with the postverbal theme slot filled, is shown in (31) (cf. [28], above):

$\begin{array}{llllll}\text { caw4 } & \text { haj5 } & \varnothing & \text { khòòj5 } & \text { haa5-lòoj4 } & \text { kiip5. } \\ \text { 2SG give } & & 1 \text { sG } & \text { five-hundred } & \text { kip } \\ \text { 'You gave me } 500 \text { kip.' } & & \end{array}$

$\begin{array}{lllll}\text { caw4 haj5 ngen2 } & \text { khòoj5 } & \text { haa5-lò̀j4 } & \text { kiip5. } \\ \text { 2SG give money } 1 \text { SG } & \text { five-hundred } & \text { kip } \\ \text { 'You gave me } 500 \text { kip (of money).' } & \end{array}$

The "float" of nominal modification to final position results from a restriction against modified or specified arguments in the nounincorporating construction. The following example, with the fully elaborated theme noun phrase in immediately postverbal position is unacceptable (as described in Section 1.1 above):

\begin{tabular}{|c|c|c|c|c|}
\hline *caw4 & haj5 & ngen2 & haa5-lòoj5 & kiip5 \\
\hline & give & money & five-hundred & kip \\
\hline
\end{tabular}

Now, consider the acceptability of the following example, where the entire theme noun phrase is intact, and where, as in (28), the relative ordering of the two postverbal participants is goal-theme:

$\begin{array}{lllll}\text { caw4 haj5 khòoj5 } & \text { ngen2 haa5-lòoj4 } & \text { kiip5. } \\ \text { 2SG give } 1 \mathrm{SG} & \text { money } & \text { five-hundred } & \text { kip } \\ \text { 'You gave me five hundred kip.' } & \end{array}$

Again, this V-goal-theme surface order is distinct in underlying structure from the incorporating structure, which has the order V-theme-goal. In (33), the theme ('money, $500 \mathrm{kip}$ ') is not in a core argument slot, but is in extraclausal Right Position. The goal khòòj ' $\mathrm{I}$ ' is in regular immediately postverbal object position, and the theme is "moved" outside the clausal core, into the periphery. This is demonstrated by the possibility of placing a sentence-final particle bòò (question marker), which marks off the right border of the clausal core (see [2], above), immediately before the theme ngen 2 'money' (as in [34a]), but not after it (as shown in [34b]), and not before the goal khò̀j5 'I' (as shown in [34c]): 

a. caw4 haj5 khòòj5 bòò3 ngen2 haa5-lòòj4 kiip5 2SG give 1SG PCL(Q) money five-hundred kip 'Did you give (it) to me, five hundred kip?'
b. *caw4 haj5 khòò5 ngen2 bòò haa5-lòò4 kiip5 $2 \mathrm{SG}$ give $1 \mathrm{SG}$ money $\mathrm{PCL}(\mathrm{Q})$ five-hundred kip '(Did you give me money, five hundred kip?)'
c. *caw4 haj5 bòò3 khòòj5 ngen2 haa5-lòòj4 kiip5 $2 \mathrm{SG}$ give $\mathrm{PCL}(\mathrm{Q})$ 1SG money five-hundred kip '(Did you give me five hundred kip?)'

This establishes that in (33) the elaborate noun phrase 'five hundred kip (of ) money' is in a peripheral slot, and the surface order V-goal-theme is not a possible one for expression of theme and goal together at the core level.

This section has shown that surface constituent order can be confusing, thanks to the possibility of movement, ellipsis, and separability of components of a single noun phrase. Nevertheless, through tests of constituency and other features of phrase structure, the underlying structures can be teased apart. We now turn to structures that deal with expression of three event participants by combining multiple verbs in a single clausal core.

\section{Serial verb means for expression of three participants in an event}

The most common and most productive way of structurally accommodating reference to three event participants in a single clause in Lao is for two verbs to share the load. The basic pattern is as follows (with verbcomplement phrases in square brackets):

$$
\left.\mathrm{NP}_{\mathrm{AGENT}}-\left[\mathrm{V} 1-\mathrm{NP}_{\text {THEME }}\right] \text {-[V2-NP } \mathrm{NOAL}_{\mathrm{GO}}\right]
$$

This template is superficially ambiguous between a two-clause and a oneclause structure, in a manner typical of serial verb constructions. If we were to view the verb-complement phrases V1-NP $\mathrm{NHEME}_{\text {The }}$ and$\mathrm{NP}_{\mathrm{GOAL}}$ as distinct clauses in themselves, we may be tempted to dismiss this as a mere "discourse strategy" for encoding three-participant events (Margetts and Austin this issue), whereby the three arguments are distributed beyond the boundaries of a single clause or sentence. But when does a two-clause strategy become a construction in itself? There is a well established preference in languages for the introduction of new arguments one clause at a time (DuBois 1987). Under the information structure pressure of yet another argument, we might identify a kind of preferred 
argument structure underlying the structure in (35), whereby a theme argument is first introduced as a verb complement on its own, after which a goal argument may be introduced in the next verb. Consider the naturalness of English sequences of just this kind - They took a knife and put it to my throat ${ }^{6}$ - where the instrument knife is first introduced as a full noun phrase object in its own clause, before being encoded pronominally in a three-place construction (where, incidentally, the subject is ellipsed, leaving only two surface noun phrases - one a pronoun - to accompany the three-place predicate $p u t$ ). Such pronominal encoding under coreference in a subsequent clause is naturally achieved by ellipsis in Lao, as in many languages.

In any case, despite the apparent two-part event structure of the construction template in (35), there are a number of reasons why it is to be considered monoclausal:

i. The construction is prosodically integrated, normally a single intonation unit contour;

ii. In the construction, the handling verb does not have the same semantic properties it does when it appears as head of an independent clause. In the handling-verb construction its meaning can be more abstract than literal "handling";

iii. It is not possible to insert material (such as marking of negation) between the two V-NP sequences and maintain the same event reading. Such insertion would normally be permissible between conjoined clauses;

iv. The construction denotes what is conceptually a "macro-event", in that the two verbs express components of what is understood to be a single event (Durie 1997; cf. Grace 1987; Foley 1997), rather than separate events that could occur at unrelated times or be under the scope of different modal operators (Bohnemeyer et al. 2004, 2007);

v. The iconicity of subevent order is not defeasible in the construction (but is defeasible in the case of the conjoined clauses);

vi. The construction shows syntactic control (i.e. subject/agent arguments of the two verbs are obligatorily interpreted as shared) while the conjoined clause reading does not (i.e. there is no crossclausal pivot).

The template in (35) can accommodate three noun phrases, and, accordingly, provides the typical (indeed the only) way for Lao speakers to describe a three-participant event with all three participants present as full arguments in the core of a single clause. ${ }^{7}$ 
Two main distinctions among constructions of this type may be termed "handling-dispatch" patterns and "dispatch-dispatch" patterns. These are so called because of the semantics of the verbs involved. "Handling verbs" describe ways of manipulating a thing, as one typically must do in "putting" it somewhere or "giving" it to someone. These include verbs with meanings like 'take', 'grab', and 'lift'. "Dispatch verbs" describe an act of transfer or placement to some goal. These include three-participant verbs such as 'give', 'send', and 'put'. The constructions described in this section are used not only to accommodate three-place predicates (i.e. verbs that "subcategorize" for three participants), but also may be used when a third argument is added to a clause, beyond the argument structure specifications of any one verb (e.g. when instruments or causers are introduced; cf., e.g., Dixon and Aikhenvald 2000).

\subsection{The handling-dispatch construction}

The handling-dispatch construction is so named due to the semantic nature and relative ordering of the two verbs involved. V1 is a verb of handling, V2 is a verb of dispatch. The construction typically describes transfer or placement (i.e. where the relevant three-place predicate is a 'give' or 'put' verb in V2 position) and takes the following form:

$$
\mathrm{NP}_{\mathrm{AGENT}}-\left[\mathrm{V}_{\mathrm{HANDLING}}-\mathrm{NP}_{\mathrm{THEME}}\right]-\left[\mathrm{V}_{\text {DISPATCH }}-\mathrm{NP}_{\mathrm{GOAL}}\right]
$$

The prototypical and most common handling verb is qaw3 'take', ${ }^{8}$ but any other coming-into-manual-control verb (e.g. ñok1 'lift' or cap2 'grab') can appear in this slot with this function. The use of a verb 'take' to host (i.e. provide a structural position for) an extra argument to the clause is typical of verb-serializing languages world wide (Lord 1993: Ch. 5; Durie 1997). The handling verb itself is not a three-participant verb (i.e. 'take', 'carry', 'hold' and their ilk do not subcategorize for three arguments), but plays the role of hosting one of the participants of a three-participant event that appears in V2 position. It is the dispatch verb - prototypically haj5 'give' or sajl 'put' — that specifies three participants.

The following examples illustrate the basic handling-dispatch pattern, all featuring qaw3 'take' as the handling verb, and in dispatch-verb position the three-participant verbs songl 'send', haj5 'give' and sajl 'put/put in', respectively. In each case, the complement of the handling verb qaw3 'take' is the theme, while the complement of the dispatch verb is the goal (note that in example [39] the theme is fronted): ${ }^{9}$ 
(37) qaw3 [vèèn2-taa3] maa2 song1 [cêk2]

take mirror-eye ('spectacles') come send chinaman khùùn2.

return

'(He) sent the spectacles back (to) the Chinaman.'

(57.8)

(38) qaw3 [ngaaw4] maa2 haj5 [qaaj4] nèè1.

take sword come give O.BRO PCL ('please')

'Please give older brother (i.e. 'me') the sword.'

(891.15)

(39) $\left[\right.$ tamlaa2 $_{i}$ ] khaw3 kaø qaw3 $\emptyset_{i}$ maa2 saj1 [thong3-sùa5]. recipe 3PL PCL take come put bag-shirt 'The recipe, he put (in) his shirt pocket.'

(40.10)

The following examples show handling verbs other than qaw3 'take' (namely, ñok1 'lift', hòop5 'carry in the arms,' and nam2 'lead, take with') in the handling-verb position:

(40) ñok1 $\ldots \begin{array}{llllll}\text { nò̀5-kèèng3 } & \tilde{n} a j 1] & \ldots & \text { saj1 [taw4-faj2]. }\end{array}$ lift pot-soup big put stove-fire '(He) lifted the big soup pot on the stove.' (925.7)

(41) [bak2 ñak1 kum3phan2] hòò5 [phuu2] pên3 M.PRFX ogre K. carry.in.arms mountain as nuaj1 maø thim5 saj1 [Ø]. CLF come discard put

'The ogre Kumphan carried the whole mountain and dropped it on (that place).'

(201.6)

(42) caø tòòng4 nam2 [saan3 nii4] haj5

IRR must lead official.letter DEM.GEN give

[sêê3naa2.qaa3maat4].

military.forces

'(We) will have to take this official letter to the military forces.' (89.11)

These more semantically specific handling verbs in (40)-(42) are less frequent than the generic, maximally abstract handling verb qaw3 'take'.

The examples seen so far in this section are genuine three-argument predications in that firstly all three arguments must be definite (contextually retrievable) for the expression to make sense, and secondly any or all 
of the arguments may be given further modification or specification in situ. First consider the following, exemplifying the handling-dispatch construction with three simple nominals:

(43) haw2 qaw3 ngen2 haj5 mèø-thaw5.

$1 \mathrm{SG}$ take money give mother-old

'I gave money to (my) mother-in-law.'

(388.5)

This structure allows a complex noun phrase like ngen2 haa5-lòòj4 kiip5 'five hundred kip (of money)' to be expressed in full, without being split by modifier float, or moved to an outer position (cf. Section 3.4 above):

(44) haw2 qaw3 ngen2 haa5-lòjj4 kiip5 haj5 mèø-thaw5. $1 \mathrm{sg}$ take money five-hundred kip give mother-old 'I gave 500 kip (of) money to (my) mother-in-law.'

As discussed in Section 3.4 above, this possibility (i.e. full elaboration of the noun phrase in situ) is not available when the theme argument is incorporated in a single-verb clausal core.

Note finally that the combination of movement and nominal ellipsis can create further possible surface constituent orders. Here is just one example, with the structure $\mathrm{NP}_{\mathrm{THEME}}-\mathrm{V}_{\mathrm{HANDLE}}$ ('take') $-\mathrm{V}_{\text {DISPATCH('give') }}$ $\mathrm{NP}_{\mathrm{GOAL}}$ resulting from fronting of the theme and ellipsis of the source:

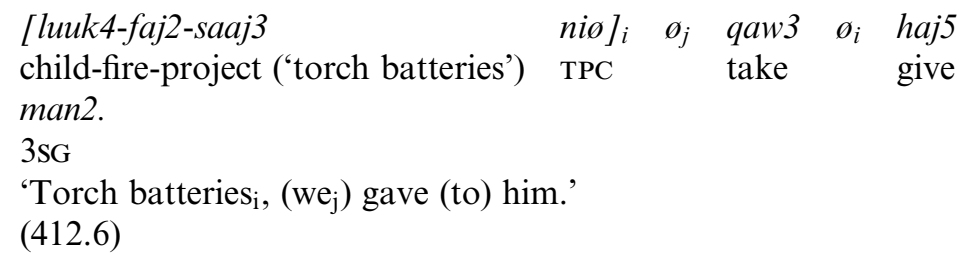

\subsection{The dispatch-dispatch construction}

The dispatch-dispatch construction is structurally similar to the handlingdispatch construction but in this case both verbs specify three participants and both express dispatch (or some kind of 'giving'):

(46) $\mathrm{NP}_{\text {AGENT }}-\left[\mathrm{V}_{\text {DISPATCH }}-\mathrm{NP}_{\text {THEME }}\right]-\left[\mathrm{V}_{\text {DISPATCH }}-\mathrm{NP}_{\mathrm{GOAL}}\right]$

Usually the second dispatch verb is haj5 'give' or saj1 'put', and the first verb expresses a more specific 'giving' or 'placing' notion, such as mòò 4 
'hand over' or songl 'send', as in the following examples (as above, the theme is direct complement of V1):

$\begin{array}{llllll}\text { phon3 thii2-sut2 } & \varnothing & \text { kaø } & \text { mòòn } 4 & \text { mùang2 } & \text { haj5 } \\ \text { result at-extreme } & & \text { PCL } & \text { hand.over } & \text { kingdom } & \text { give } \\ \text { sin2saj2. } & & & & & \end{array}$

$\mathrm{S}$.

'The final result (was that he) handed over the kingdom to Sinxay.' (205.10)

(48) khòoj5 siø song1 lot1-cak2 haj5 phòò1.

$1 \mathrm{SG}$ IRR send motorcycle give father

'I'm going to deliver the motorcycle to Dad.'

As shown above for other examples, there are other possible surface orders due to movement and ellipsis. The following examples show postposing, and fronting, respectively, of the theme, giving the two surface orders $\mathrm{NP}_{\text {AGENT }}-\mathrm{V}_{\text {DISPATCH }}-\mathrm{V}_{\text {DISPATCH }}-\mathrm{NP}_{\text {THEME }}$ and $\mathrm{NP}_{\text {THEME }}-\mathrm{NP}_{\text {AGENT }}-$ $\mathrm{V}_{\text {DISPATCH }}-\mathrm{V}_{\text {DISPATCH }}-\mathrm{NP}_{\mathrm{GOAL}}:^{10}$

(49) haw2 caø mòò 4 $\emptyset_{i}$ haj5 $\emptyset_{j}$ [saang4-maa4-ngua21SG IRR hand.over give elephant-horse-cowkhuaj2-sing1-khòòng3-paa3nakaan3-kèèw4-vèèn3-ngen2-kham2 $]_{i}$ buffalo-things-stuff-of.various.kinds-crystal-rings-silver-gold 'I'll hand over (to them) livestock, goods, and many precious items.' (88.3)

(50) [thuk1-sing1-thuk1-jaang1 kiaw1.kap2 lùang1 nii4] $]_{i}$ each-thing-each-kind about matter DEM.GEN qaaj4 mòò $4 \quad o_{i}$ haj5 nòòng $4_{j}$ O.BRO hand.over give Y.SIB 'Everything concerning this matter, older brother (i.e. 'I') hands over to younger sibling (i.e. 'you').'

(94.12)

Given that both V1 and V2 positions allow dispatch verbs, there are naturally some dispatch verbs that may appear in either position. For example, the dispatch-dispatch construction in (48) with songl 'send' in V1 slot can be rephrased as a handling-dispatch construction with songl 'send' as V2 (and qaw3 'take' as V1): ${ }^{11}$

(51) khòoj5 siø qaw3 lot1-cak2 song1 phò̀1. $1 \mathrm{SG}$ IRR take motorcycle send father 'I'm going to deliver the motorcycle to Dad.' (attested) 


\section{3. 'Telling' and 'showing' - addition of a third 'reception' verb}

There is no Lao verb meaning 'show', but there is a verb bò̀k5 'tell', which may appear as a single verb with three arguments in a topiccomment construction (as described in Section 1.2 above):

(52) [lùang1 nii4 $]_{\mathrm{TH}}$ khòòj5 bòòk5 caw4 lèèw4. story DEM.GEN 1SG tell 2SG PFV 'This story, I've told you already.'

Other verbs of 'telling' or 'showing', such as vaw4 'say', do not display this pattern:

$\begin{array}{llllll}\text { *lùang1 } & \text { niï } & \text { khòoj5 } & \text { vaw4 } & \text { caw4 } & \text { lèèw4. } \\ \text { story } & \text { DEM.GEN } & 1 \mathrm{SG} & \text { say } & 2 \mathrm{SG} & \mathrm{PFV} \\ \text { '(This story, I've said you already.)' } & & \end{array}$

Verbs of communication such as vaw4 'say', law1 'relate, tell', and saaj3 'screen (e.g. a film)' may enter into a variation on the two-verb structure sketched in (35), above, using the basic dispatch verb haj5 'give' in V2 position, and with the addition of a final verb of 'reception' (usually fang 2 'listen' or bengl 'look'), giving the following frame:

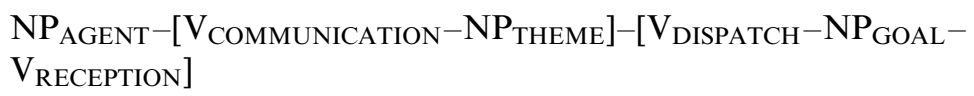

$\mathrm{NP}_{\text {AGENT }}-\left[\mathrm{V}_{\text {COMMUNICATION }}-\mathrm{NP}_{\text {THEME }}\right]-\left[\mathrm{V}_{\text {DISPATCH }}-\mathrm{NP}_{\mathrm{GOAL}}-\right.$ $\mathrm{V}_{\text {RECEPTION] }}$

Here are four examples (the first expressing what [53] tried to express):

$\begin{array}{llllllll}\text { lùang1 nii4 } & \text { khòoj5 } & \text { vaw4 } & \text { haj5 } & \text { caw4 } & \text { fang2 } & \text { lèèw4. } \\ \text { story } & \text { DEM.GEN } & 1 \mathrm{SG} & \text { say } & \text { give } & \text { 2SG } & \text { listen } & \text { PFV }\end{array}$
'This story I've told to you already.'

(56) khòòj5 dajø vaw4 Ø haj5 caw4 fang2 nòoj5-nùng1. 1SG ATTN say give $2 \mathrm{SG}$ listen a.little 'I did tell you (this joke) a little ...'

(57) nòòng4 mii2 qiø-ñang3 $\ldots$ khuam2 khat2-khòòng5 naj2 Y.SIB have what NZR get.in.the.way in qok2 naj2 caj3 khòò-haj5 vaw4 haj5 qaaj4 fang2. chest in heart request-give say give O.BRO listen 'What does younger sibling (i.e. 'you') have? ... (What) difficulty in (your) heart? Please tell (it) to older brother (i.e. 'I').' (199)

(58) man2 saaj3 nang3 haj5 kuu3 beng1. $3 \mathrm{SG}$ screen movie give $1 \mathrm{sg}$ look 'S/he screened a movie (for) me (to) watch.' 
This manner of expressing "showing" and "telling" involving three verbs together - "communication", "dispatch", and "reception" — is an areal feature in mainland Southeast Asia, also found in languages such as Vietnamese, Khmer, and Cantonese (cf., e.g., Matthews and Yip 1994: 138).

\subsection{Other three-participant event descriptions involving two verbs}

Occasionally, serial verb structures expressing three-participant events differ from the constructions described so far in that the two verbs involved do not obviously belong to the semantic types hitherto identified (i.e. "handling", "dispatch", "communication", and "reception"). The next two examples involve a three-participant verb kèem4 "to snack on something with a drink', which specifies an agent and two theme arguments (namely, a snack food and an alcoholic beverage):

$\begin{array}{lllll}\text { haw2 kin3 hua3-khaw1 kaj1 kèèm4 } & \text { bia3. } \\ 1 \mathrm{PL} \text { eat knee chicken snack-on-with-liquor } & \text { beer } \\ \text { 'We snacked (on) chicken knees (with) beer.' } & \end{array}$

$\begin{aligned} & \text { hua3-khaw1 kaj1 } \\ & \text { knee haw2 }\end{aligned}$ (kin3) kèm4
bia3.
beer
'Chicken $1 \mathrm{PL}$ eat
nnees, we snacked (on with) beer.'

Here is another example that also does not neatly fit the patterns examined so far:

(61) paj3 tat2 maj4 maa2 lò̀m4 hua4.

go cut wood come encircle fence

'(We) went and cut wood (and) encircled a fence (around the rice fields).'

While neither main verb in this example (tat2 'cut', lòom4 'encircle') specifies three participants, the example nevertheless describes a cohesive event involving three participants. This is a typical case of serialization becoming tighter such that an erstwhile series of distinct clauses, with topical arguments ellipsed, takes on the shape of a single clause.

\subsection{Other functions for the multi-verb pattern}

There are further instances of the basic pattern illustrated in (35) (i.e. NP1-[V1-NP2]-[V2-NP3]), in which three arguments are expressed, 
but in which neither of the two verbs subcategorizes for all these three. Let me briefly mention some common cases, mostly involving qaw3 'take' in V1 position (see Enfield 2002 for further detail).

First, the complement of V1 qaw3 'take' may be an instrument in some action. The subject of qaw3 'take' performs the action expressed in V2. In these cases it is possible to omit the V1-NP2 combination without compromising the general event semantics; that is, the resulting expression remains true of any event of which (62) is true. In the following example, I have put square brackets around omissible material (as usual, any of the noun phrases are omissible on their own):

(62) man2 [qaw3 sòòn3 maa2] cam4 kacèè3 fong4 3sG take arrow come ram lock come.apart leej2. altogether

'He broke the lock apart [with an arrow].'

(lit. 'He took an arrow [and] rammed the lock [and it] came apart completely.')

(176.17)

Second, the theme (i.e. complement of qaw3 'take') may be a causee (cf. Enfield 2002: 19). (Here, in contrast to previous examples, it is NP2, the complement of 'take', not NP1, which performs the action of the following verb phrase):
$\varnothing \quad$ qaw3 siang2-miang5 take S.M.
maa2
suaj1
$\varnothing$.
come help

'(He would) get Siang-Miang to come (and) help (him).'

(93.16)

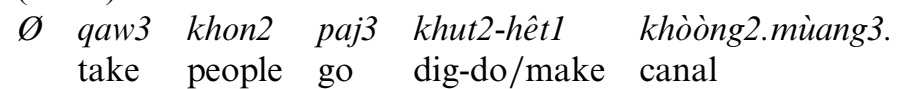

'(They) got the people to dig the canals.' (267.9)

A third possibility may be called an effected object construction, in which the theme and goal arguments are coreferential, but where the goal is the theme having been transformed by some process predicated or suggested by V2 (usually hêt1 'make'):

(65) qaw3 fùang2 maø hêt1 hun1.

take straw come make effigy

'(They) made effigies with straw.'

(lit. 'They took straw and made effigies.')

(228) 
A final use of the two-verb construction using qaw3 'take' in V1 position is in "pretransitive" constructions (also known as disposal constructions; cf. Chao 1968; Li and Thompson 1981; Jagacinski 1987; Enfield 2002), in which the theme argument is complement of both V1 and V2 (i.e. despite there being two transitive verbs in the structure, there remains a total of only two arguments): ${ }^{12}$

phen1 kaø qaw3 toø-nii4 $\quad$ paj3 hian2
3.HON PCL take CLF-DEMr2-kan3.
'They also did study this.'
(lit. 'They also did take this [and] go [and] study [it].')
(270.6)

This is hardly different in meaning to the following simple transitive expression:

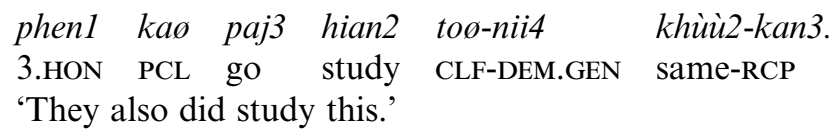

The distinction between (66) and (67) is partly related to pragmatic factors concerning information structure. In terms of event structure, however, the presence of two verbs in (66) gives a finer granularity to the event structure, with explicit mention of two subcomponents of the event that might otherwise have been packed into the semantics of a single verb, or simply inferred. Having two verbs in (66) allows separation of a twoargument event (learning something) into two subevents, first cominginto-control-of (literally taking-in-hand) an undergoer, and second a controlled action upon that undergoer. A single participant is thus given two roles, first treated as a theme, second as a patient. Although expressions such as (66) are two-place, they display the same event packaging characteristics as the "three-place" serial verb constructions focused upon here. In common is a construal of the event structure as bifurcated: first, control over a theme, then, dispatch. The example demonstrates that what might otherwise look like a dedicated three-participant event structure has a broader functionality in the language's resources for event representation.

A final case of a derived three-argument structure involves the use of haj5 'give' in V2 position, marking a peripheral beneficiary, rather than a literal recipient of a theme (cf. Section 5.1 below):
khon4-din3-khon4-saaj2 haj5 khaw3 hanaa3. dig.up-earth-dig.up-sand give 3PL PCL '(I) dug up earth and sand for them, you know.' (350.5) 
(69)

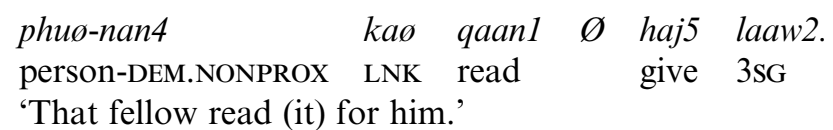

In neither of these examples does the complement of haj5 'give' actually receive anything. While in (69) one could argue that the goal receives knowledge or information, the goal participant in (68) is purely a benefactor. In either case, however, a third participant is introduced.

Given the centrality of serial verb constructions in the grammar of Lao (Enfield in press), it is no surprise that they may serve across a range of argument structure functions, including subtypes of three-place predications, as well as special construals of two-place events. We now turn to a different type of strategy for expressing three-place predications, where a third argument is hosted by a preposition in an external adjunct.

\section{An oblique strategy for expressing three-participant events}

A typologically common strategy for expressing three-place predicates is to host one or another of the nonsubject arguments as an adjunct. In Lao, this only works for recipient/goal arguments. Nontheme arguments may be overtly marked as peripheral adjuncts. Marking is done either by coverbs such as nam2 'with/from' (a verb-preposition, elsewhere a main verb 'accompany, lead'; example [70]), or by dedicated adjunct-markers such as kap2 'with, and' (example [71]), kèèl 'to' (example [72]), and duaj4 'with' (example [73]):

(70) laj1 ñaat4-qaw3 tòòn1 siin4 [nam2 maa3 $]_{\mathrm{ADJT}}$. chase grab-take lump meat with/from dog '(She) chased the dog to grab the lump of meat from it.' (911.5)

(71) khòoj5 dajø haj5 sanñaa2 $\left[\begin{array}{lll}k a p 2 & \text { caw4 }\end{array}\right]_{\mathrm{ADJT}}$ lèèw4. 1SG ATTN give promise with $2 \mathrm{SG}$ PFV 'I did give my promise to you already.' (857.10)

(72) caø dajø law1 nithaan2 pakòò5 thammaq1 phùal IRR ATTN relate fable.tale comprise dharma in.order.to pen3 khatiq2-kham2-sang1-sòòn3 haj5 [kèè1 be provision-word-order-teach give to qanuson2-hun1-lang3] $]_{\mathrm{ADJT}}$. younger.generations 
'I'll tell some dharmic tales as lessons to give to the younger generations.'

(838.4)

(73) hêt1 khòòn-tabòòng thaa2 [duaj4 namo-sii3 dam3 make stick-torch apply with water-paint black lùam5] $]_{\mathrm{ADJT}}$.

shiny

'(They) made torch-sticks (and) painted (them) with shiny black paint.'

Also, with placement verbs like saj1 'put' or vaang2 'place', locative prepositions such as theng 2 'on' and naj2 'in' may be used to mark goals:

(74) kuu3 vaang2 pùm4 [theng2 toq2 $]_{\mathrm{ADJT}}$.

$1 \mathrm{SG}$ place book on table

'I put the book on the table.'

(75) khòòj5 saj1 nam4 [naj2 mòò nii4 $]_{\text {ADJT }}$.

$1 \mathrm{SG}$ put water inside pot DEM.GEN

'I put water in this pot.'

Compare example (75) with the following handling-dispatch example, which features the same three-participant verb (sajl 'put') and the same three arguments:

(76) khòoj5 qaw3 nam4 saj1 mòò5 nii4.

$1 \mathrm{sg}$ take water put pot DEM.GEN

'I put water (in) this pot.'

The next examples combine a handling-dispatch serial-verb structure with additional marking of the goal by naj2 'in':

(77) phen1 qaw3 ñang3 saj1 naj2 kap2 han5 kaø 3 HON take what put in box TPC.PCL FOC.PCL

bòø huu4.

NEG know

'What he put in that box, (I) don't know.' (875)

(78) qaa3 hanø qaw3 laan3 paj3 sùang1 vaj4 naj2 aunt PCL take nephew go hide keep in kòòng3 dòòk-maj4.

pile flower

'The aunt hid her nephew in a pile of flowers.' (180) 
Naj2 'in' in both these examples is omissible (i.e. removal of naj2 from these examples would not significantly change the meaning, and would not affect the examples' grammaticality). (Vaj4 'keep' is also optional here in the same sense.) However, some three-participant verbs require that the goal take explicit adjunct-marking. For example, while the threeparticipant verb haajl 'decant' is otherwise semantically appropriate as a dispatch verb, it may not appear in V2 slot in a typical handling-dispatch construction (Section 4.1 above). In other words, it can only take as its direct complement a theme argument:

khòoj5 haaj1 nam4 saj1 kèè4.
1SG decant water put bottle
'I decanted the water into a bottle.'
*khòoj5 qaw3 nam4 haaj1 kèèw4.
1sG take water decant bottle
'(I decanted the water into a bottle.)'

The ungrammatical example (80) shows the dispatch verb taking a direct goal argument. When the dispatch verb is haajl 'decant' (among others such as thim5 'discard' and thòòk5 'pour out'), saj1 'put' must be used to mark off the goal argument (kèèw4 'bottle' in example [80]), so that the latter is not a direct complement of the theme-only verb haajl 'decant':

(81) khòoj5 qaw3 nam4 haaj1 saj1 kèèw4.
1sG take water decant put bottle
'I decanted (the) water into a bottle.'

\section{Concluding discussion}

Lao speakers may select from a suite of conventional structures for description of three-participant events. Heavy constraints apply when the clausal core contains only one verb, in which case one of the three event participants is accommodated outside the clausal core (by extraposition) or in the constrained format of incorporation. Otherwise, ellipsis relieves one or more arguments from placing any structural burden on overt syntactic structure (where the "burden" could involve any kind of structure at all - the point here being that ellipsis simply relieves the grammar of having to find a way of morphosyntactically hosting one or more of the three arguments involved). The ellipsis strategy is available for contextually retrievable arguments, that is, arguments already definite and known from the context. This presupposition of prior introduction of the relevant argument is in line with patterns of preferred argument structure 
(DuBois 1987). If arguments are first introduced in structurally lighter (one- or two-place) expressions, then one or more arguments will already be available for ellipsis or other reduced format when a three-place expression is used. A three-argument predicate in natural discourse should then seldom if ever have to appear with three fully elaborated noun phrases. To really establish how this works, further investigation needs to go beyond single clauses and single sentences, and consider stretches of discourse in which three-participant event descriptions are constructed and elaborated clause by clause.

In Lao, the only genuine possibility for having three full arguments explicit in a single clausal core is provided by verb serialization. With a handling verb like 'grab' or 'take' in V1 position, two verbs share the load in a single-clause complex predicate. But the function of this structure is not simply to accommodate the expression of three arguments (cf. discussion of examples [66] and [67] above). A dispatch-type serial verb construction may also be used in the expression of a two-participant event, as the following examples show:

$$
\begin{aligned}
& \text { a. man2 thim5 ngen2. } \\
& \text { 3SG discard money } \\
& \text { 'S/he discarded (the) money.' } \\
& \text { b. man2 qaw3 ngen2 thim5. } \\
& \text { 3sG take money discard } \\
& \text { 'S/he took the money (and) discarded (it).' }
\end{aligned}
$$

While the handling-verb serial construction exemplified in (82b) is not restricted to the description of three-participant events, its structure and the event construal it encodes happen to be highly compatible with typical three-place predications such as 'give' and 'put'. The serial verb strategy not only provides structurally for three full arguments, but brings with it a construal of the three-participant event as "bifurcated" and controlled. The single-clause constructions in (82a) and (82b) express different construals of the internal structure of the same event. The presence of two verbs in (82b) brings to a two-place event the logic of a three-place event. It brings finer granularity to the event structure by explicitly mentioning two event subcomponents that might otherwise have been packed into the semantics of a single verb, or simply inferred. The (82b) structure bifurcates a simple transitive event ('she discards money'), separating it into two subevents, first a taking-in-hand and coming-into-control of something ('money'), and second a now-enabled controlled action upon that thing. A single participant ('money') is construed first as a theme and second as a patient. The construction results in this theme-patient argument having a higher degree of individuatedness and definiteness (Enfield 2002: 
24; cf. Li and Thompson 1981: 483), both properties being associated with increased transitivity (Hopper and Thompson 1980). Similarly associated with higher transitivity is the higher degree of control/agentivity specified by the construction.

Upon reviewing the range of strategies that Lao speakers employ in describing three-participant events, we may ask: Why does a language use just the combination of strategies it uses? The most important strategies used by Lao speakers for the morphosyntactic encoding of three-participant events involve (a) ellipsis of arguments where they are contextually retrievable, thereby avoiding the need to syntactically accommodate them, (b) removal of one argument into an extra-clausal position where it does not require structural accommodation in the clausal core, and (c) using serial verb constructions in which two or more verbs distribute the argument-taking load in the clausal core. That Lao speakers use just this combination of strategies - zero anaphora, topic-slot extraposition, and verb serialization - reflects their centrality in the typological profile of the language.

Received 26 May 2005

Revised version received

Max Planck Institute for Psycholinguistics

31 May 2006

\section{Appendix. Abbreviations}

\begin{tabular}{llllll}
\hline PCL & particle & Q & question & FOC.PCL & focus particle \\
PFV & perfective & $1 / 2 / 3$ & 1st/2nd/3rd p. pronoun & TPC.PCL & topic particle \\
M.PRFX & masculine prefix & $\varnothing$ & ellipsed argument & HES.PCL & hesitation particle \\
CLF & classifier & SG & singular & RCP & reciprocal \\
IRR & irrealis & PL & plural & ATTN & attainment \\
NEG & negation & HON & honorific & EXPR & expressive \\
O.BRO & older brother & Y.SIB & younger sibling & NONPROX & non proximal \\
DEM & demonstrative & GEN & general & & \\
\hline
\end{tabular}

N.b. Single capital letter with period (e.g. D.) for gloss of proper names, period between morphemes to indicate semantically unanalyzable morphology (e.g. THERE.IS). ${ }^{*}(x)$ and $\left({ }^{*} x\right)$ indicate that the example is ungrammatical if $x$ is excluded, and included, respectively.

The transliteration of Lao used here follows IPA standard except for the following: $e=$ schwa; $\hat{e}=$ high-mid front vowel; $\grave{e}=$ low front vowel; $\grave{o}=$ low back vowel; $\grave{u}=$ high back unrounded vowel; $n g=$ velar nasal; $\tilde{n}=$ palatal nasal; $q=$ glottal stop. Lexical tone is indicated by syllable-final numeral, as follows: $1=$ mid level (33); $2=$ high rising (35); $3=$ low rising (13); $4=$ high falling (51); $5=$ low falling (31); Ø-neutral, de-stressed. 


\section{Notes}

1. This article was originally drafted in 2000 as part of a University of Melbourne project Three-Place Predicates in the Languages of the World, which convened at the Australian Linguistic Institute in Melbourne in July 2000. The resulting joint publication project was eventually abandoned. A number of the issues and examples discussed here are treated in Enfield (2002), which concentrates exclusively on the verbs qaw3 'take' and haj5 'give'. Examples marked by section number in brackets are from Enfield (2001), a corpus of spontaneous spoken Lao collected in Vientiane in 1996-1997, representing a variety of speaker and discourse types. Other examples are attested or constructed, and discussed in consultation with native speakers. Thanks in particular to Syban Khoukham and Pitsana Vayaphanh for patient consultation. For comments and discussion I thank Bill Foley, Nick Evans, Bhuvana Narasimhan, and fellow participants in the Workshop on the Linguistic Encoding of Three-Participant Events, MPI Nijmegen, May 14-16, 2003. I thank the Max Planck Society for field and research support. Correspondence address: MPI for Psycholinguistics, P.O. Box 310, 6500 AH, the Netherlands. E-mail: nick.enfield@mpi.nl.

2. Some of the absorption strategies described by Margetts and Austin (this issue) also occur in Lao, but since these do not deal with the syntactic management of three arguments, they are not included here.

3. The limited evidence for subject as a grammatical entity is probably due to argument structure phenomena alone, rather than anything operating at the level of constituent structure or functional structure (Manning 1996). Nevertheless, it is convenient in the description of Lao grammar to be able to refer to subject.

4. See appendix for guide to abbreviations in glosses.

5. One might think from this example that the referent of ' $O$ ' could be khum3 'hole'. However, khum3 'hole' cannot appear as direct object of fang3 'bury'. Apparently, a direct object of fang 3 'bury' must refer to the substance in which something is buried, not to the empty space that provides a place for the thing to be buried.

6. Source: Former POW: 'We were like Custer', CNN.com, April 14, 2003.

7. Thus, Preferred Argument Structure (DuBois 1987), normally a preference, is here a rule of grammar.

8. The relevant meaning of 'take' does not include the deictic motion component of English take (as in I took the books to school). The meaning of qaw3 'take' is merely 'take in hand' or 'pick up'.

9. In these examples, the verb maa2 'come' appears as a directional particle on the second subclause. This is common (cf. Enfield 2002). While the presence of maa2 'come' in these examples may suggest a clause chain ("take the sword, come, give it to me") rather than serial verb analysis, there are reasons to think that the directional verb is not an independent clausal head: 1) it is omissible without appreciable change in referential meaning, 2) it is prosodically fully incorporated (i.e. fully destressed and prosodically dependent on the following element), 3) its "subject" need not be the main actor in the event, but rather the orientation of the central action (see example [39] in which it is not the actor that moves toward a deictic centre, rather the action of putting the recipe in his pocket is directed toward the actor's deictic center). See Note 10, below.

10. In (49) $\mathrm{NP}_{\mathrm{GOAL}}$ is ellipsed under contextual retrievability.

11. This example is ambiguous, since (as noted in Section 4.5 below), the direct object of the handling verb can also be interpreted not as a theme but as an instrument. Thus, (51) can also mean 'I'm going to send Dad (somewhere) with the motorcycle' (i.e. 'I'm 
going to take the motorcycle and send Dad somewhere (on it)'). This second meaning was the one intended in context.

12. V2 in these constructions is almost always directly preceded by a directional particle ( paj3 'go' or maa2 'come'; see examples). As discussed in Note 7, above, the effect is not mere predication of motion or direction of action. Structurally, it appears that the 'go/come' element is not necessarily a preverbal marker of V2, but may be a complement of the phrase headed by V1. This conclusion is based on facts about ellipsis of NP2. Generally, if NP2 is to be ellipsed (as its discourse status may allow), both V1 (qaw3 'take') and the directional particle ( paj3 'go'/maa2 'come') may remain, but if the entire "V1-phrase" (e.g. qaw3 'take' and its nominal complement NP2) is to be ellipsed, it is usually much more natural to (and sometimes impossible not to) also remove the 'go/come' verb that follows NP2, suggesting it is attached to the V1-NP2 phrase. See Enfield (2002: 17) for discussion.

\section{References}

Austin, Peter K.; Bowden, John; Evans, Nicholas; and Margetts, Anna (2000). Three-place predicates in the languages of the world. Unpublished manuscript, University of Melbourne.

Baker, Mark C. (1996). On the structural positions of themes and goals. In Phrase Structure and the Lexicon, L. Zaving and R. Rooryck (eds.), 7-34. Dordrecht: Kluwer.

Bohnemeyer, Jürgen, Enfield, N. J.; Essegbey, James; and Kita, Sotaro (2004). The macroevent property: the segmentation of motion paths and causal chains. Paper presented at the conference Event Representation in Mind and Language, September 2004, Eugene, Oregon.

—; Enfield, N. J.; Essegbey, James; Ibarretxe-Antuñano, Iraide; Kita, Sotaro; Lüpke, Friederike; Ameka; and Felix, K. (2007). Principles of event segmentation in language: the case of motion events. To appear in Language.

Borg, A. J. and Comrie, Bernard (1984). Object diffuseness in Maltese. In Objects: Towards a Theory of Grammatical Relations, Frans Plank (ed.), 109-126. London: Academic Press.

Bresnan, Joan (2001). Lexical-Functional Syntax. London: Routledge.

- and Moshi, Liobi (1990). Object asymmetries in comparative Bantu syntax. Linguistic Inquiry 21, 147-185.

Chao, Yuen Ren (1968). A Grammar of Spoken Chinese. Berkeley: University of California Press.

Dixon, R. M. W. (1994). Ergativity. Cambridge: Cambridge University Press.

- and Aikhenvald, A. Y. (eds.) (2000). Changing Valency: Case Studies in Transitivity. Cambridge: Cambridge University Press.

Dryer, Matthew (1986). Primary objects, secondary objects, and the antidative. Language $62,808-845$.

DuBois, John W. (1987). The discourse basis of ergativity. Language 63(4), 805-855.

Durie, Mark (1997). Grammatical structures in verb serialization. In Complex Predicates, Alex Alsina, Joan Bresnan, and Peter Sells (eds.), 289-354. Stanford, CA: CSLI Publications.

Enfield, N. J. (2002). Functions of 'give' and 'take' in Lao complex predicates. In Collected Papers on Southeast Asian and Pacific Languages, Robert Bauer (ed.), 13-36. Canberra: Pacific Linguistics.

- (2004). Nominal classification in Lao: a sketch. Sprachtypologie und Universalienforschung 57(2/3), 117-143. 


\section{N. J. Enfield}

- (in press). Verbs and multi-verb sequences in Lao. In The Tai-Kadai Languages, A. V. N. Diller and Jerold Edmondson (eds.). London: Routledge/Curzon.

Foley, William A. (1997). Anthropological Linguistics: An Introduction. Oxford: Blackwell.

Gil, David (1987). Definiteness, noun phrase configurationality, and the count-mass distinction. In The Representation of (In) definiteness, Eric Reuland and Alice G. B. ter Meulen (eds.), 254-269. Cambridge, MA: MIT Press.

Givón, Talmy (1984). Direct object and dative shifting: semantic and pragmatic case. In $\mathrm{Ob}$ jects: Towards a Theory of Grammatical Relations, Frans Plank (ed.), 151-182. London: Academic Press.

Goldberg, Adele (1995). Constructions: A Construction Grammar Approach to Argument Structure. Chicago: University of Chicago Press.

Grace, George (1987). The Linguistic Construction of Reality. London: Croom Helm.

Hopper, Paul J.; and Thompson, Sandra A. (1980). Transitivity in grammar and discourse. Language 56, 251-299.

Hudson, Richard A. (1992). So-called 'double objects' and grammatical relations. Language $68,251-276$.

Jagacinski, Ngampit (1987). The Tai Lue of Xipsongbanna in China's Yunnan Province: description and a study of the OV order in the "AU construction. Unpublished doctoral dissertation, Ohio State University. Ann Arbor: UMI Microfilms.

Langacker, Ronald W. (1991). Concept, Image, and Symbol: The Cognitive Basis of Grammar. Berlin and New York: Mouton de Gruyter.

Li, Charles N. and Thompson, Sandra A. (1976). Subject and topic: a new typology of language. In Subject and Topic, Charles N. Li (ed.), 457- 489. New York: Academic Press.

- and Thompson, Sandra A. (1981). Mandarin Chinese: A Functional Reference Grammar. Berkeley: University of California Press.

Lord, Carol (1993). Historical Change in Serial Verb Constructions. Amsterdam: John Benjamins.

Manning, Christopher D. (1996). Ergativity: Argument Structure and Grammatical Relations. Stanford, CA: CSLI Publications.

Matthews, Stephen and Yip, Virginia (1994). Cantonese: A Comprehensive Grammar. London: Routledge.

Mithun, Marianne (1984). The evolution of noun incorporation. Language 60, 847-894.

Newman, John (1996). Give: A Cognitive Linguistic Study. Berlin and New York: Mouton de Gruyter.

—(ed.) (1997). The linguistics of Giving. Amsterdam: John Benjamins.

Sapir, Edward (1921). Language. New York: Harcourt Brace Jovanovich. 